\title{
Diagnostic and Therapeutic Approach in a Case of Severe Acute Baclofen Poisoning
}

\author{
Cristina Iolanda VIVISENCO ${ }^{1,2}$, Coriolan Emil ULMEANU ${ }^{1,2}$
}

\begin{abstract}
Baclofen is a structural analogue of gamma-aminobutyric acid with central myorelaxant effect. Ingestion of a toxic dose of baclofen induces a clinical presentation with neurological, cardiac, respiratory and metabolic expression, sometimes life-threatening. The authors present the case of a 17-year old teenage girl who developed deep coma, sinus bradycardia, first-degree atrioventricular block, arterial hypertension and hyperglycemia after ingesting a large dose of baclofen. The patient was successfully treated with supportive measures. Early diagnosis and prompt therapeutic intervention are key-steps in the management of acute baclofen poisoning.
\end{abstract}

Keywords: baclofen, poisoning, overdose, bradycardia, atrioventricular block, coma, hyperglycemia.

\section{Rezumat}

Baclofenul este un analog structural al acidului gama-aminobutiric cu efect miorelaxant central. Ingestia unei doze toxice de baclofen induce o prezentare clinică cu manifestări neurologice, cardiovasculare, respiratorii și metabolice, uneori amenințătoare de viață. Autorii prezintă cazul unei adolescente în vârstă de 17 ani care a dezvoltat comă profundă, bradicardie sinusală, bloc atrioventricular de gradul I, hipertensiune arterială și hiperglicemie după ingestia unei doze mari de baclofen. Pacienta a fost tratată cu succes prin măsuri suportive. Diagnosticul precoce și intervenția terapeutică promptă sunt pașii cheie în gestionarea cazurilor de intoxicație acută cu baclofen.

Cuvinte cheie: baclofen, intoxicație, supradoză, bradicardie, bloc atrioventricular, comă, hiperglicemie.

\section{BACKGROUND}

Baclofen ( $\beta$ - (4-chlorophenyl) -gamma-aminobutyric acid) is a structural analogue of gamma-aminobutyric acid (GABA), the main inhibitory neurotransmitter in the central nervous system. The pharmacological utility of baclofen is related to the central myorelaxant effect, being classically prescribed in patients with cerebral palsy or multiple sclerosis ${ }^{1}$. Recently, baclofen was used to reduce symptoms associated with alcohol withdrawal syndrome ${ }^{2}$.
Acute poisoning with baclofen is not frequently reported in pediatric departments, being more common in adult population. In young children, toxic ingestion may occur accidentally due to age-related curiosity and negligence of parents, who leave medication at the reach of children. In teenagers, intoxication can occur by drug ingestion for suicidal or demonstrative purposes, but also for recreational use ${ }^{3}$. The use of intrathecal pumps with baclofen in the treatment of muscle spasticity has brought a new possibility of intoxication by overdosing the medication in these patients ${ }^{4}$.

\footnotetext{
1 Department of Toxicology, "Grigore Alexandrescu" Emergency Children Hospital, Bucharest, Romania

${ }^{2}$ Department of Pediatrics, "Carol Davila" University of Medicine and Pharmacy, Bucharest, Romania
}

\section{Corresponding author.}

Cristina Iolanda VIVISENCO, „Grigore Alexandrescu” Emergency Children Hospital, 30-32 lancu de Hunedoara Boulevard, $1^{\text {st }}$ District, 011743, Bucharest, Romania.

E-mail: iolanda.vivisenco@gmail.com 
Clinical findings in acute poisoning with baclofen are mainly related to the central nervous system, the cardiovascular and respiratory systems ${ }^{5}$.

\section{CASE REPORT}

A 17-year-old patient from rural environment was sent to our hospital from another medical unit for coma and cardiac conduction disorder. 30 minutes before presentation in the first medical unit, after a family conflict, the patient ingested in a suicide attempt 20 tablets containing $25 \mathrm{mg}$ of baclofen (Lioresal ${ }^{\circledR}$ ) (total dose 500 $\mathrm{mg} \approx 8.5 \mathrm{mg} / \mathrm{kgc}$ ). The patient was drowsy with a score of 12 on Glasgow Coma Scale (GCS) and the following vital parameters: 36.1 Celsius degrees, respiratory rate $14 \mathrm{bpm}$, oxygen saturation measured by pulse oximetry $\left(\mathrm{SaO}_{2}\right) 90 \%$, heart rate $55 \mathrm{bpm}$, blood pressure 120/80 $\mathrm{mmHg}$. The therapeutic approach consisted of decontamination by gastric lavage, administration of activated charcoal by nasogastric tube, intravenous infusion with crystalloid solutions and oxygen supplementation through a facial mask. An electrocardiogram (ECG) was performed which showed sinus bradycardia with heart rate $55 \mathrm{bpm}$ and first-degree atrioventricular $(\mathrm{AV})$ block $(\mathrm{PR}$ interval $=290 \mathrm{~ms})$. Considering the cardiac conduction disorder and progressive deterioration of consciousness, it has been decided to send the patient to our clinic.

The patient arrived in our clinic 4 hours after ingestion in deep coma (score 6 on GCS) with marked hypotonia and abolished osteotonic reflexes. The vital signs were: 36.4 Celsius degrees, respiratory rate 20 bpm, $100 \% \mathrm{SaO}_{2}$ (under 100\% oxygen through facial mask), heart rate $44 \mathrm{bpm}$, blood pressure $136 / 80 \mathrm{mmHg}$ (over 99th percentile). ECG indicates sinus bradycardia with heart rate $44 \mathrm{bpm}$, first-degree AV block (PR interval $=230 \mathrm{~ms}$ ) and normal duration of QRS complex (90ms) and QTc interval (410ms) (Figure 1). Laboratory tests showed mixed acidosis $(\mathrm{pH} 7.22$, base excess $-2 \mathrm{mmol} / 1$, bicarbonate $20 \mathrm{mmol} / 1$, partial pressure of carbon dioxide $62 \mathrm{mmHg}$ in peripheral venous blood gas sample), hyperglycemia $(201 \rightarrow 464 \mathrm{mg} / \mathrm{dl})$ and mild hyponatremia $(131 \mathrm{mmol} / \mathrm{l})$. Kidney and liver functional tests were within normal ranges. The patient was admitted to the Intensive Care Unit (ICU) where continuous cardiac monitoring was performed. She received perfusion with crystalloid solutions to speed up toxic elimination, atropine in bolus for bradycardia and continuous insulin infusion for hyperglycemia. No treatment for high blood pressure was initiated as the highest values recorded were $139 \mathrm{mmHg}$ for systolic component and $82 \mathrm{mmHg}$ for the dyastolic one. Since the patient was breathing spontaneously, the ventilator support by orotracheal intubation was not necessary and the airway was kept permeable by the insertion of a Guedel tube. In the first 12 hours, the patient remained bradycardic. Afterwards, heart rate increased to $70-80 \mathrm{bpm}$, and the PR interval duration on ECG record returned to normal values. Blood pressure was maintained in the first 12 hours at values over the 95 th percentile. 24 hours after admission, the patient recovered from coma, presenting only drowsiness on physical exam. The haemodynamic parameters (heart rate 90 bpm, blood presure $123 / 59 \mathrm{mmHg}$ ) as well as laboratory tests were within normal limits. After 36 hours of hospitalization, the patient was transferred in the Toxicology Department for further monitoring. On day 5 , she was discharged, with biological parameters, ECG and echocardiographic exam in the normal limits.

\section{DISCUSSION}

Baclofen is a specific gamma-aminobutyric acid type $\mathrm{B}\left(\mathrm{GABA}_{\mathrm{B}}\right)$ receptor agonist. These receptors are diffusely distributed in the brain and spinal cord and their activation leads to decreased calcium transport and intracellular cyclic adenosine monophosphate production. Baclofen binds to presynaptic and postsynaptic $\mathrm{GABA}_{\mathrm{B}}$ receptors. Binding of GABA or baclofen to presynaptic receptors leads to hyperpolarization of presynaptic terminals which inhibits release of neurotransmitters such as catecholamines, glutamate and substance $P$ from excitatory spinal pathways. Presynaptic binding involves also GABA-ergic autoreceptors with hyperpolarization of presynaptic terminals and decreasing of GABA release, displaying an excitatory effect. Binding to postsynaptic $\mathrm{GABA}_{\mathrm{B}}$ receptors hyperpolarizes nerve cells, displaying an inhibitory effect. Thus, binding of baclofen to $\mathrm{GABA}_{\mathrm{B}}$ receptors exerts both excitatory and inhibitory effects, but at therapeutic doses the latter dominate. However, this dual action may explain the over-lap symptomatology in the clinical features of baclofen overdose ${ }^{1,5}$.

Acute poisoning has been reported in adolescents and adults who have ingested between 80 and $2500 \mathrm{mg}$ of baclofen ${ }^{3,6}$. Doses above $200 \mathrm{mg}$ have been associated with the occurrence of severe neurological symptoms (coma, seizures, delirium), need for admission in ICU and prolonged hospitalization ${ }^{6}$. Death has been reported after ingestion of $1250-3000 \mathrm{mg}$ of baclofen ${ }^{7,8}$. The 
Figure 1. Sinus bradycardia. First-degree atrioventricular block.

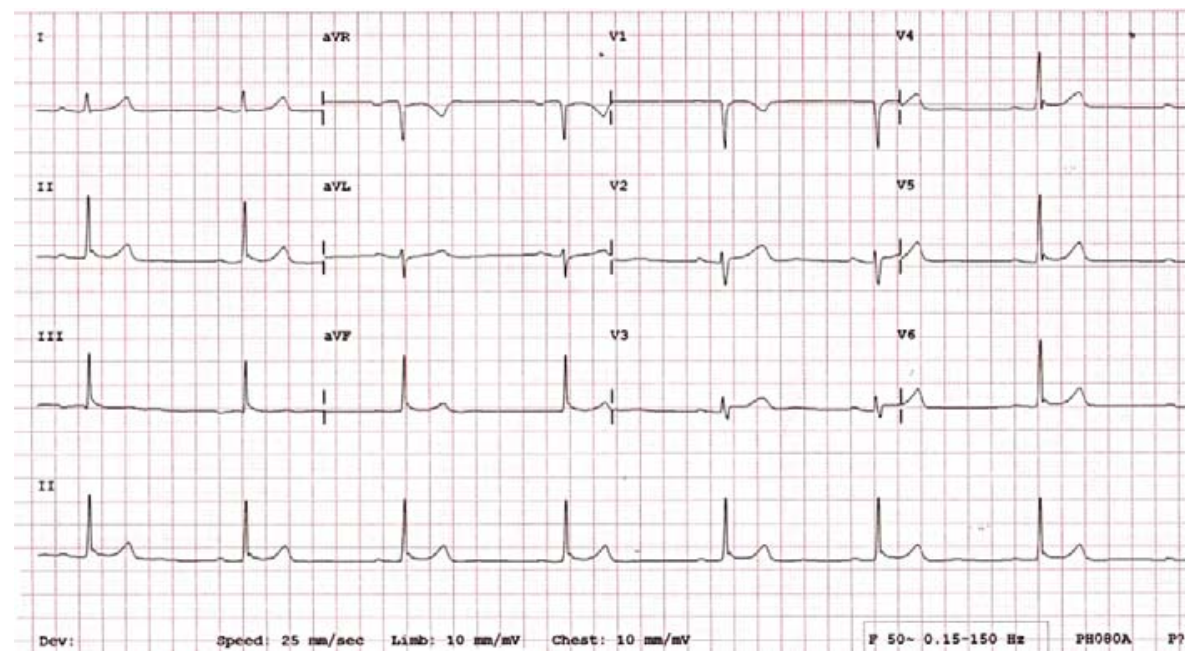

serum level of baclofen confirms acute poisoning when the therapeutic level of $0.08-0.4 \mathrm{mg} / 1$ is exceeded ${ }^{7}$. In our case, the anamnesis identified the total ingested dose, which falls within the severity range specified above. Dosage of serum level was not possible in our institution.

The clinical manifestations of acute baclofen intoxication occur 2 to 6 hours after ingestion of a toxic dose and usually involves the central nervous system, the respiratory and cardiovascular system. The most common manifestations are respiratory failure, coma, seizures, hypotonia with hyporeflexia and hypothermia ${ }^{6,9,10}$. The baclofen-induced coma is particularly profound and long-lasting, mimicking brain death in some cases ${ }^{11}$. The spectrum of cardiovascular manifestations includes the following: tachycardia or bradycardia, hypotension or hypertension, conduction disorders (long QTc interval, first-degree AV block), premature atrial and ventricular contractions, supraventricular tachyarrhythmias (paroxysmal tachycardia, flutter, fibrillation) ${ }^{6,9,12}$.

In our case, the manifestations of acute poisoning involved the central nervous system (deep coma, hypotonia, hyporeflexia), the cardiovascular system (sinus bradycardia, first-degree AV block, arterial hypertension) and the metabolic balance (hyperglycemia). Perry and colleagues published a study about a group of 18 adolescents who developed symptoms of acute poisoning after ingesting 3 to 30 pills of $20 \mathrm{mg}$ baclofen at a party. The most common clinical signs were coma, hypothermia, bradycardia, arterial hypertension and hyporeflexia ${ }^{3}$. Rise of glucose serum level has been reported in patients with baclofen overdose ${ }^{9}$. An animal experiment conducted by Sim and colleagues showed that baclofen has a dose-dependent hyperglycemic effect, and GABAB receptors in the spinal cord play an essential role in this process ${ }^{13}$.

The therapeutic approach to acute poisoning with baclofen is mainly supportive, as we have done in this case. Evidence of toxicity after acute ingestion is a criterion for admission in the $\mathrm{ICU}^{5}$. In pediatric patients, gastrointestinal decontamination and activated charcoal administration are recommended if the ingested dose exceeds $5 \mathrm{mg} / \mathrm{kg}^{10}$. Respiratory depression may require orotracheal intubation and assisted ventilation. In Perry's study, 9 patients required assisted ventilation for an average of 40 hours $^{3}$. There is no specific antidote for this intoxication. The use of physostigmine has been proposed to reduce the effects on the central nervous system - drowsyness and respiratory depression, but the reported results were contradictor $y^{14,15}$. Severe arterial hypertension should be treated with fast acting antihypertensive agents such as sodium nitroprusside, because hemodynamic status may evolve very quickly to arterial hypotension ${ }^{3,9}$. Non-responsive hypotension to intravenous fluid may require vasopressor support with noradrenaline ${ }^{5}$. Symptomatic bradycardia may respond to atropine ${ }^{16}$. Extrarenal epuration techniques have not been proven effective in acute poisoning with baclofen, except for patients with renal impairment ${ }^{17}$.

\section{CONCLUSION}

Baclofen acute poisoning is a serious and life-threatening condition, that involves the nervous, cardiovascular and respiratory systems, but also the metabolic balance of the organism. The most important steps in the approach of the poisoned patient are early diagnosis and prompt clinical and paraclinical evaluation. The 
symptomatic patient should be treated in the ICU. Supportive treatment is essential in managing these cases.

\section{Compliance with ethics requirements:}

The authors declare no conflict of interest regarding this article.

\section{References}

1. Stroescu V. Bazele farmacologice ale practicii medicale. 7th ed. Bucureşti: Editura Medicală; 2001.

2. Liu J, Wang L. Baclofen for alcohol withdrawal. Cochrane Database of Systematic Reviews. 2017;(8).

3. Perry HE, Wright RO, Shannon MW, Woolf AD. Baclofen overdose: drug experimentation in a group of adolescents. Pediatrics. 1998; 101(6): p. 1045-8

4. Yeh RN, Nypaver MM, Deegan TJ. Baclofen toxicity in an 8-year-old with an intrathecal baclofen pump. J Emerg Med. 2004; 26(2): p. 163-7.

5. Stewart E, Tormoehlen M. Baclofen. In J B, editor. Critical Care Toxicology Diagnosis and Management of the Critically Poisoned Patient. 2nd ed. Philadelphia, USA: Springer; 2017. p. 111927.

6. Leung NY, Whyte IM, Isbister GK. Baclofen overdose: defining the spectrum of toxicity. Emerg Med Australas. 2006; 18(1): p. 77-82.

7. Cooper DJ, Bergman J. Massive baclofen overdose. Crit Care Resusc. 2000; 2(3): p. 195-7.

8. Haubenstock A, Hruby K, Jäger U, Lenz K. Baclofen (Lioresal) intoxication report of 4 cases and review of the literature. $J$ Toxicol Clin Toxicol. 1983; 20(1): p. 59-68.

9. Nugent S, Katz MD, Little TE. Baclofen overdose with cardiac conduction abnormalities: case report and review of the literature. J Toxicol Clin Toxicol. 1986; 24(4): p. 321-8.
The authors declare that all the procedures and experiments of this study respect the ethical standards in the Helsinki Declaration of 1975, as revised in 2008(5), as well as the national law. For this study the approval of the hospital's ethics committee was requested and obtained.

10. Dasarwar N, Shanbag P, Kumbhare N. Baclofen intoxication after accidental ingestion in a 3-year-old child. Indian J Pharmacol. 2009; 41(2): p. 89-90.

11. Sullivan R, Hodgman MJ, Kao L. Baclofen overdose mimicking brain death. Clin Toxicol (Phila). 2012; 50(2): p. 141-4.

12. Roberge RJ, Martin TG, Hodgman M. Supraventricular tachyarrhythmia associated with baclofen overdose. J Toxicol Clin Toxicol. 1994; 32(3): p. 291-7.

13. Sim YB, Park SH, Kang YJ. Effect of GABA receptor agonists or antagonists injected spinally on the blood glucose level in mice. Neurochem Res. 2013; 38(5): p. 1055-62.

14. Müller-Schwefe G, Penn RD. Physostigmine in the treatment of intrathecal baclofen overdose. Report of three cases. J Neurosurg. 1989; 71(2): p. 273-5.

15. Saltuari L, Baumgartner $\mathrm{H}$, Kofler M. Failure of physostigmine in the treatment of acute severe intrathecal baclofen intoxication. N Engl J Med. 1990; 322(21): p. 1533-4.

16. Ferner RE. Atropine treatment for baclofen overdose. Postgrad Med J. 1981; 57(671): p. 580-581.

17. Chen KS, Bullard MJ, Chien YY. Baclofen toxicity in patients with severely impaired renal function. Ann Pharmacother. 1997; 31(11): p. 1315-20. 